\title{
SOIL NUTRIENT CHARACTERISTICS OF GRAIN TO GREEN PROGRAM OF MAIN VEGETATION TYPES IN A SMALL WATERSHED, WULING MOUNTAIN AREA, CHINA
}

\author{
LUO, J. ${ }^{1,2}-$ NIU, Y.D. ${ }^{1}-$ WANG, Y. ${ }^{1}-$ ZHANG, Y. ${ }^{1}-$ YAO, M. ${ }^{1,2}-$ TIAN, Y. X. ${ }^{1,2^{*}}-$ ZHOU, X. L..$^{12^{*}}$ \\ ${ }^{1}$ Hunan Forestry Academy, Changsha, Hunan, China \\ (e-mail: luojia993@sina.com-- Jia Luo) \\ ${ }^{2}$ Hunan Cili Forest Ecosystem State Research Station, Cili, Hunan, China \\ (e-mail:6118408@126.com-- Min Yao) \\ *Corresponding authors \\ e-mail: tyx2019@sina.com-- Yuxin Tian; zxling36@263.net-- Xiaoling Zhou
}

(Received $11^{\text {th }}$ Jan 2019; accepted $8^{\text {th }}$ Mar 2019)

\begin{abstract}
In the present investigation, soil nutrient characteristics of three stands were studied. The soil organic matter content showed a hierarchy of Pinus massoniana forest > slope farmland > Eucommia ulmoides plantation> maple-Cinnamomum camphora mixed plantation in horizontal direction. However, with an increasing depth of soil layer, the soil organic matter content showed a decreasing pattern. The soil total nitrogen phosphorus and potassium contents of different vegetation types followed a pattern of Eucommia ulmoides plantation > maple-Cinnamomum camphora mixed plantation > Pinus massoniana forest > slope farmland. In this, the soil total nitrogen and phosphorus content decreased significantly with the increase in soil depths. The soil available nitrogen, potassium and phosphorus content of different vegetation types exhibited a pattern which follows slope farmland > Eucommia ulmoides plantation > maple-Cinnamomum camphora mixed plantation > Pinus massoniana forest. The soil available nitrogen, potassium and phosphorus content decreased with the soil depth increase. The pattern followed for soil trace elements of different vegetation types were Eucommia ulmoides plantation > slope farmland > Pinus massoniana forest > maple-Cinnamomum camphora mixed plantation. The average contents of trace elements in 0-10 and 10-20 cm of soil layer followed a gradation of $\mathrm{Fe}>\mathrm{Mn}>\mathrm{Zn}>\mathrm{Pb}$ $>\mathrm{Ni}>\mathrm{Cu}>\mathrm{Cd}$. 'Grain to Green Program' increased the soil nutrient content of different vegetation types, and soil nutrient content decreased with the soil depth increase. In this study, significant correlations were observed among soil nutrient elements in different vegetation types.
\end{abstract}

Keywords: organic matter and total nutrients contents, available nutrients contents, contents of soil microelements, correlation, three typical vegetation types

\section{Introduction}

The types of forest stands affect the accumulation, distribution and circulation of nutrients in soil. Thus, different vegetation types stimulate different soil nutrient contents (Xiang et al., 2014) and affect the formation and development of soil (Huang, 2000; David et al., 2018). Soil, as an essential component for supporting vegetation and is one of the important environmental factors affecting the survival, structure and function of plant communities (He et al., 2017). In forest ecosystem, soil nutrients serve as major factor affecting vegetation growth (Jiang et al., 2011). Since 1970s, with the rapid development of precision agriculture and introduction of geostatistics, the study on soil nutrients has drawn much attention. Chen et al. (2017) studied the soil nutrient content of different vegetation types which provides clues to understand the relationship between forest growth and soil nutrient formation. The study of soil nutrient change is significant to understand the soil fertility and nutrient cycling mechanisms of different vegetation types (Finzi et al., 1998; Augusto et al., 2002). Many authors have evaluated 
the performances of different small-watershed forest stands in respect to water conservation and sediment yield reduction, the rules of sediment yield and runoff yield, and the regulation of vegetation restoration patterns for a long time (Lopes and Canfield, 2004; Yuan et al., 2006). The characteristics of soil nutrients and their influencing factors were also studied, but these works focused on the effects of variation of individual nutrient elements (Liu and Tong, 2005; Wei and Shao, 2007), spatial heterogeneity (Wang et al., 2002; Wang et al., 2007), soil types (Wen et al., 2005), land utilization patterns (Wang et al., 2001) and site conditions (McGrath et a1., 2001; Latty et al., 2004) on the characteristics of soil nutrients. Some authors studied the soil nutrients, soil nutrient output mechanisms, microbial diversity and enzymatic activity of different forest stands (Peng et al., 2018; Hu et al., 2018; Zhang et al., 2018). However, the quantitative analysis of the availability of various soil nutrients to different forest stands was rarely studied (Yan et al., 2007). In China forest soil nutrients have been studied in a widespread manner extending from north to south (Gong et al., 2005; Huang et al., 2018). But the soil nutrient contents of different vegetation types after returning from farmland to forests and vertical heterogeneity of the soil nutrients were scarcely investigated (Cao et al., 2016). Especially, the hilly regions subjected to erosion in the south China with different water and soil erosion characteristics were rarely reported. Therefore, for the present study the Wuling Mountain small watershed was found as a typical example of hilly erosion regions of South China. A systematic study on the total and available nutrients and trace elements of soil covered by Pinus massoniana forest, Eucommia ulmoides plantation, maple-Cinnamomum camphora mixed plantation and slope farmland with different vegetation types was targeted. All these study sites were previously farmlands but returned to forests (the so called 'Grain to Green') later. Moreover, it was anticipated that the results of the present investigation could be beneficial for the soil conservation after returning farmland to forests as well as for vegetation optimization pattern selection and manual regulation in the hilly erosion regions of South China.

\section{Field test region}

The study area was located in the Nverzhai small watershed $\left(111^{\circ} 12^{\prime} 42.836^{\prime \prime} \mathrm{E}\right.$ and $29^{\circ} 25^{\prime} 27.582^{\prime \prime} \mathrm{N}$ ) of Wuling mountain region in West Hunan Province of China. This watershed was well closed, containing a second-class small tributary of the Lishui River, and generally extended from north to south. It was a low mountain range with a total area of $3.15 \mathrm{~km}^{2}$. The lowest elevation (outlet of the main ditch) was $210 \mathrm{~m}$ and the highest elevation was $917.4 \mathrm{~m}$ above MSL. The main ditch was about $1.2 \mathrm{~km}$ in length and the longitudinal slope of the main ditch was about $28.4 \%$. The forest coverage rate in this region was over $80 \%$. The vegetation types were mainly characteristic to dense secondary forests after returning from farmland habitats. The soil-forming rock of the area was mainly sandy shale with yellow-red acidic soil. The light, heat and rainfall were abundant. The annual average sunshine time reached $1440 \mathrm{~h}$, and the annual average temperature was $16^{\circ} \mathrm{C}$. The annual average precipitation was about $1400 \mathrm{~mm}$, and the annual frost-free period was 216-269 days. A prototype monsoon humid climate of the middle subtropical mountains prevailed in the area. The main vegetation types included Eucommia ulmoides plantation, Pinus massoniana forest, Citrus reticulata plantation and slope farmland. 


\section{Methods}

\section{Test fields and measurements}

In August 2015, three typical vegetation types of P. massoniana forest, E. ulmoides plantation and maple-cinnamomum camphora mixed plantation under similar growing environmental conditions (such as slope, slope aspect and altitude) and after returning from farmland were selected. With reference to a slope farmland, three blocks of test fields $(20 \times 20 \mathrm{~m})$ were selected for each vegetation type. The distance between two study sites was above $200 \mathrm{~m}$. The height, diameter at breast height (DBH) and growing conditions of all trees with DBH values $\geq 5 \mathrm{~cm}$ were measured and recorded. Three shrub blocks $(2 \times 2 \mathrm{~m})$ were randomly arranged in each test field, and the shrub species, number of plants and average height were recorded. Five herbaceous blocks $(1 \times 1 \mathrm{~m})$ were also arranged in each test field, and the species, number, coverage and average height of the herbaceous plants were recorded. This work is guided on "Observation Methodology for Long-term Forest Ecosystem Research" of National Standards of the People's Republic of China (GB/T 33027-2016). The test field characteristics of each forest stand are shown in Table 1.

Table 1. Basic characteristics of vegetation in the experimental plots

\begin{tabular}{|c|c|c|c|c|}
\hline Stand type & $\begin{array}{c}\text { Pinus massoniana } \\
\text { forest }\end{array}$ & $\begin{array}{c}\text { Eucommia } \\
\text { ulmoides plantation }\end{array}$ & $\begin{array}{c}\text { Maple-Cinnamomum } \\
\text { camphora mixed } \\
\text { plantation }\end{array}$ & Slope farmland \\
\hline $\begin{array}{l}\text { Geographic } \\
\text { coordinates }\end{array}$ & $\begin{array}{l}111^{\circ} 13^{\prime} 17^{\prime \prime} \mathrm{E} \\
29^{\circ} 25^{\prime} 21^{\prime \prime} \mathrm{N}\end{array}$ & $\begin{array}{l}111^{\circ} 12^{\prime} 46^{\prime \prime} \mathrm{E} \\
29^{\circ} 25^{\prime} 23^{\prime \prime} \mathrm{N}\end{array}$ & $\begin{array}{l}111^{\circ} 12^{\prime} 45^{\prime \prime} \mathrm{E} \\
29^{\circ} 25^{\prime} 22^{\prime \prime} \mathrm{N}\end{array}$ & $\begin{array}{l}111^{\circ} 12^{\prime} 45^{\prime \prime} \mathrm{E}, \\
29^{\circ} 25^{\prime} 24^{\prime \prime} \mathrm{N}\end{array}$ \\
\hline Elevation $/ \mathrm{m}$ & 400 & 313 & 333 & 305 \\
\hline Slope / $\left({ }^{\circ}\right)$ & 35 & 15 & 18 & 25 \\
\hline Aspect & Southwest & Northeast & Northeast & Northeast \\
\hline Soil parent materials & Malmstone & Malmstone & Plate shale & Shale \\
\hline Soil type & Red Soil & Red Soil & Yellow Soil & Yellow Soil \\
\hline Origin & Secondaryforest & Plantation forest & Secondary forest & - \\
\hline $\begin{array}{c}\text { Density } \\
/\left(\text { individual } \cdot \mathrm{hm}^{-2}\right)\end{array}$ & 2366.7 & 5005 & 3507 & - \\
\hline Mean tree height $/ \mathrm{m}$ & 8 & 5.9 & 7 & - \\
\hline Mean DBH/cm & 12.3 & 9 & 7.8 & - \\
\hline Canopy density & 0.6 & 0.8 & 0.85 & - \\
\hline $\begin{array}{l}\text { Main plants in shrub } \\
\text { and herbaceous layer }\end{array}$ & $\begin{array}{c}\text { Quercus fabri, } \\
\text { Rhododendron simsii, } \\
\text { Stenoloma chusanum. } \\
\text { Patrinia villosa } \\
\end{array}$ & $\begin{array}{c}\text { Rubus hirsutus, } \\
\text { Rubus corchorifolius }\end{array}$ & $\begin{array}{c}\text { Gynostemma } \\
\text { pentaphyllum, Mallotus } \\
\text { philippensis, Pteridium } \\
\text { aquilinum }\end{array}$ & $\begin{array}{c}\text { Camellia oleifera, } \\
\text { Rhus chinensis, } \\
\text { Agrimonia pilosa }\end{array}$ \\
\hline
\end{tabular}

\section{Soil sampling and processing}

Three blocks $(5 \times 5 \mathrm{~m})$ were selected in each forest stand. After removing dry branches and fallen leaves, the soil sampling was done following the " $\mathrm{S}$ "-shaped 5-point method. Soil layers at depths of $0-10$ and $10-20 \mathrm{~cm}$ were separately sampled. The samplings were made in triplicates. After an air-drying process, the stones and roots in the soil samples were removed and the samples were crushed and screened with a screen ( $1 \mathrm{~mm}$ mesh size) for the measurements of relevant indicators.

\section{Determination of soil chemical indicators}

In October 2015, the soil nutrient indices were measured following Soil Agrochemical Analysis (Qi et al., 2008). The total nitrogen content was determined 
with the semi-micro Kjeldahl method and $\mathrm{NaOH}$-melting-molybdenum-antimony colorimetry was used to determine the total phosphorus content. For measuring total potassium content, $\mathrm{NaOH}$-melting-flame-photometry was used. The alkali-hydrolyzed nitrogen content was determined with the alkali-hydrolyzed diffusion method. Available $\mathrm{P}$ was measured with the sodium-bicarbonate, extraction-molybdenum-antimonycolorimetry method while for the available potassium content, the $\mathrm{NH}_{4} \mathrm{OAc}$-leachingflame-photometry was used. The organic matter content was determined with the potassium-dichromate-volumetry-heating-method. The iron, zinc and manganese contents were determined with the diethylene tri-amine penta acetic-acid-leaching-ICP (DTPA-ICP) method. For the determination of copper, cadmium, nickel and lead contents the ICP-MS method was used. The ICP-MS is displayed in Figure 1.

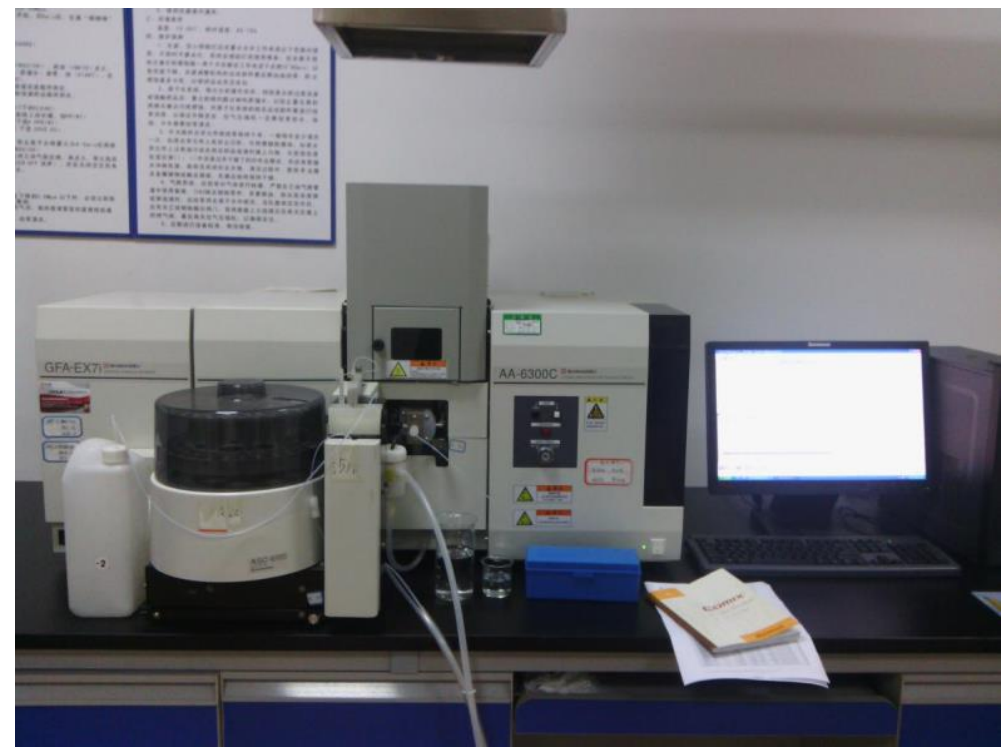

Figure 1. The equipment of ICP-MS used in this study

\section{Data processing}

The software SPSS 17.0 and R3.3.4 were used for data processing and analysis. Oneway ANOVA and least significant difference (LSD) methods were applied for the comparison of the differences between the data groups. The software R3.3.4 was used to study the correlations between different soil nutrients.

\section{Results and analysis}

\section{Organic matter and total nutrient contents in the soil of different forest stands}

The differences in the contents of soil organic matter and total nutrients among different stands were significant (Figure 2). From 0-10 cm soil layers, the organic matter contents were ranked: Pinus massoniana forest $>$ Eucommia ulmoides plantation $>$ maple-Cinnamomum camphora mixed plantation $>$ slope farmland. The organic matter content in the soil of Eucommia ulmoides plantation in the 10-20 cm soil layer reached a maximum, 1.80 times the lowest value (slope farmland). Its concentration in the soil of different stands through $0-20 \mathrm{~cm}$ soil layers were ranked as follows: The 
Pinus massoniana forest $\left(27.44 \pm 9.37 \mathrm{~g} \cdot \mathrm{kg}^{-1}\right)>$ Eucommia ulmoides plantation $\left(23.88 \pm 3.15 \mathrm{~g} \cdot \mathrm{kg}^{-1}\right)>$ maple-Cinnamomum camphora mixed plantation $\left(16.98 \pm 1.98 \mathrm{~g} \cdot \mathrm{kg}^{-1}\right)>$ slope farmland $\left(13.38 \pm 1.86 \mathrm{~g} \cdot \mathrm{kg}^{-1}\right)$. With the increase of soil depth, the contents of soil organic matter in the soil of all stands decreased. For instance, the content of soil organic matter in the soil of the secondary Pinus massoniana forest decreased from $36.81 \pm 0.002$ to $18.07 \pm 0.22 \mathrm{~g} \cdot \mathrm{kg}^{-1}$.

The average contents of total nitrogen, total phosphorus and total potassium in the 0-20 cm soil layers of different forest stands followed the order of Eucommia ulmoides plantation > maple-Cinnamomum camphora mixed plantation > Masson Pine secondary forest $>$ slope farmland. Besides, the contents of total nitrogen and total phosphorus in the soil of all stands decreased with the increase of soil depth, similar to the trend of the contents of organic matter against soil depth. For instance, the contents of total nitrogen and total phosphorus in the $0-10 \mathrm{~cm}$ soil layer of Eucommia ulmoides plantation were $1.64 \pm 0.10$ and $1.14 \pm 0.01 \mathrm{~g} \cdot \mathrm{kg}^{-1}$, respectively. While those in the $10-20 \mathrm{~cm}$ soil layer were lower $\left(1.46 \pm 0.15\right.$ and $1.07 \pm 0.03 \mathrm{~g} \cdot \mathrm{kg}^{-1}$, respectively). The contents of total nitrogen and phosphorus in the $10-20 \mathrm{~cm}$ soil layer of slope farmland was also lower than those in the $0-10-\mathrm{cm}$ soil layer.

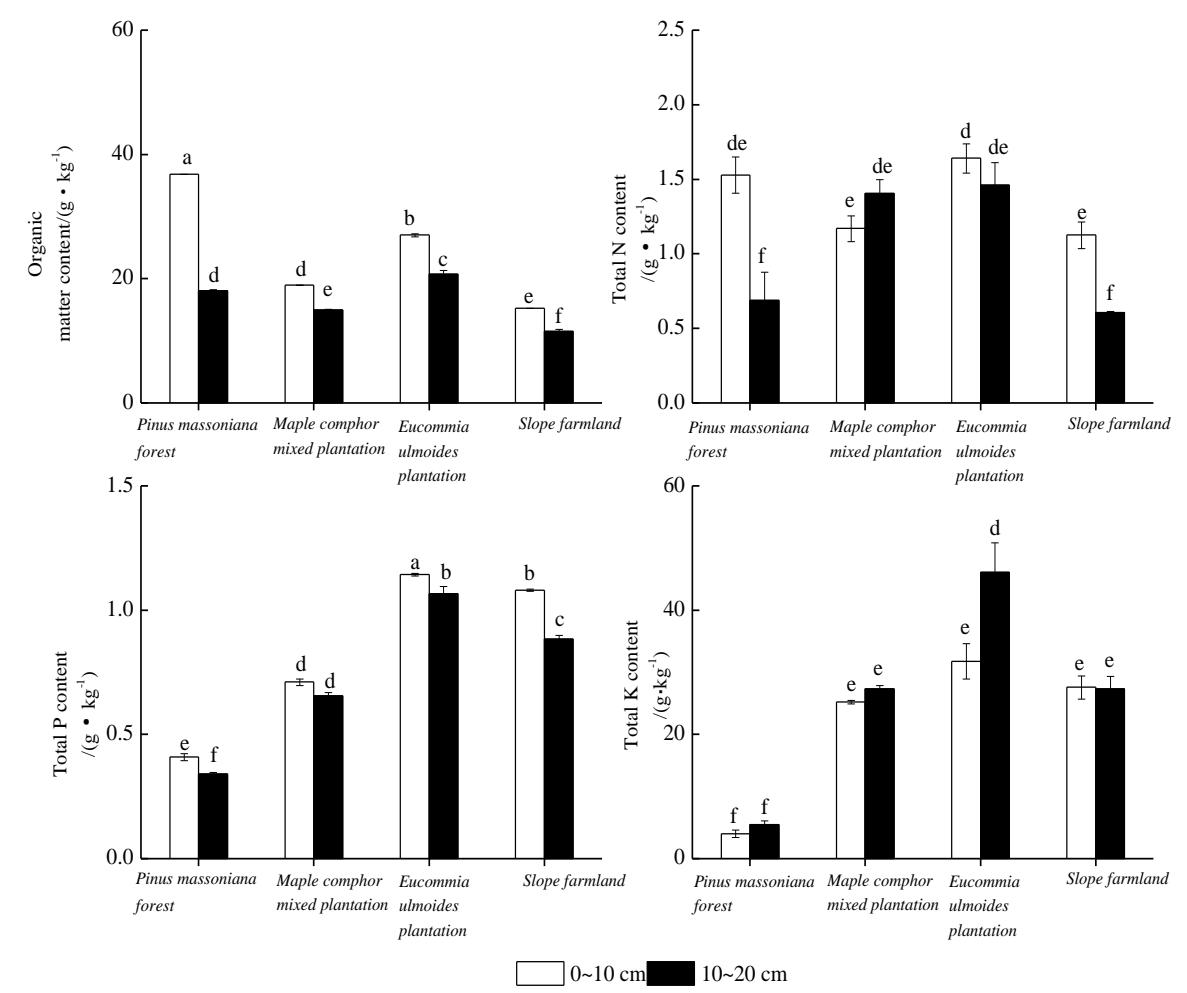

Figure 2. Soil organic matter and total nutrient content of different stand types (different lowercase letters represent the significance of difference between different vegetation types in the same soil layer, $P<0.05)$

The contents of total potassium in the $0-10 \mathrm{~cm}$ soil layers of different vegetation types were ranked as follows: Eucommia ulmoides plantation $\left(31.79 \pm 2.85 \mathrm{~g} \cdot \mathrm{kg}^{-1}\right)>$ slope farmland $\left(27.61 \pm 1.87 \mathrm{~g} \cdot \mathrm{kg}^{-1}\right)>$ maple-Cinnamomum camphora mixed plantation $\left(25.22 \pm 0.30 \mathrm{~g} \cdot \mathrm{kg}^{-1}\right)>$ Pinus massoniana forest $\left(4.02 \pm 0.60 \mathrm{~g} \cdot \mathrm{kg}^{-1}\right)$. The contents in 
the 10-20-cm soil layers were ranked as follows: Eucommia ulmoides plantation > maple-Cinnamomum camphora mixed plantation > slope farmland > Pinus massoniana forest. The contents of total potassium in soil of different stands increased with the increase of soil depth except for slope farmland. It can be conjectured that the accumulation of potassium in the Pinus massoniana forest was lower, while that in the Eucommia ulmoides plantation was higher; most of the potassium for uptake was concentrated on the upper soil.

\section{Available nutrient contents in soil of different forest stands}

Table 2 shows the total contents of available nitrogen, phosphorus and potassium in the $0-10$ and $10-20 \mathrm{~cm}$ soil layers of different stands. These are ranked as follows: Slope farmland > Eucommia ulmoides plantation > maple-Cinnamomum camphora mixed plantation > Pinus massoniana forest. Soil available nitrogen from the study sites have been ranked as follows: Pinus massoniana forest > Eucommia ulmoides plantation > maple-Cinnamomum camphora mixed plantation $>$ slope farmland. The state of available phosphorus was ranked as follows: Slope farmland > Eucommia ulmoides plantation > Pinus massoniana forest > maple-Cinnamomum camphora mixed plantation. The available potassium was ranked as follows: Slope farmland > Eucommia ulmoides plantation > maple-Cinnamomum camphora mixed plantation > Pinus massoniana forest. Both the contents of available phosphorus and available potassium in the soil of slope farmland were significantly higher than those in the soil of other vegetation types $(\mathrm{P}<0.05)$, which may be related to the fertilization management. The available nitrogen content in the soil of maple-Cinnamomum camphora mixed plantation was higher, probably because its vegetation coverage was the highest. Liu et al. (2006) suggested that the vegetation coverage was positively affected by height, biomass, community species diversity and soil nutrient contents. In this study, the maple-Cinnamomum camphora mixed plantation had the highest vegetation coverage, so the available nutrient contents in the soil of this forest were higher.

Table 2. Soil available nutrient content of different stand types

\begin{tabular}{|c|c|c|c|c|}
\hline Stand type & $\begin{array}{c}\begin{array}{c}\text { Soil } \\
\text { layer/cm }\end{array} \\
\end{array}$ & $\begin{array}{c}\text { Available } \\
\text { Nitrogen } /\left(\mathbf{m g} \cdot \mathbf{k g}^{-1}\right) \\
\end{array}$ & \begin{tabular}{|c|} 
Available \\
Phosphorus $/\left(\mathrm{mg} \cdot \mathrm{kg}^{-1}\right)$ \\
\end{tabular} & $\begin{array}{c}\text { Available } \\
\text { Potassium } /\left(\mathrm{mg} \cdot \mathrm{kg}^{-1}\right) \\
\end{array}$ \\
\hline \multirow{2}{*}{ Pinus massoniana forest } & $0-10$ & $108.36 \pm 2.11 \mathrm{a}$ & $0.87 \pm 0.68 \mathrm{bc}$ & $50.45 \pm 1.24 \mathrm{c}$ \\
\hline & $10-20$ & $59.36 \pm 1.48 \mathrm{~b}$ & $0.58 \pm 0.04 \mathrm{a}$ & $4.30 \pm 0.01 \mathrm{a}$ \\
\hline \multirow{2}{*}{$\begin{array}{l}\text { Maple-Cinnamomum camphora } \\
\text { mixed plantation }\end{array}$} & $0-10$ & $87.36 \pm 0.01 \mathrm{~cd}$ & $0.72 \pm 0.04 \mathrm{ab}$ & $86.66 \pm 0.01 \mathrm{~d}$ \\
\hline & $10-20$ & $78.40 \pm 2.96 \mathrm{de}$ & $0.50 \pm 0.14 \mathrm{a}$ & $39.23 \pm 1.25 \mathrm{~b}$ \\
\hline \multirow{2}{*}{ Eucommia ulmoides plantation } & $0-10$ & $96.60 \pm 0.84 \mathrm{ab}$ & $1.42 \pm 0.01 \mathrm{~d}$ & $131.53 \pm 0.01 \mathrm{~g}$ \\
\hline & $10-20$ & $70.56 \pm 4.22 \mathrm{c}$ & $1.08 \pm 0.02 \mathrm{c}$ & $49.21 \pm 2.1 \mathrm{c}$ \\
\hline \multirow{2}{*}{ Slope farmland } & $0-10$ & $71.12 \pm 2.44 \mathrm{ab}$ & $3.60 \pm 0.05 \mathrm{f}$ & $116.56 \pm 0.01 \mathrm{f}$ \\
\hline & $10-20$ & $62.70 \pm 2.01 b c$ & $1.97 \pm 0.02 \mathrm{e}$ & $109.08 \pm 0.01 \mathrm{f}$ \\
\hline
\end{tabular}

The different lowercase letters indicate the significance of difference between different vegetation types in the same soil layer $(P<0.05)$

As shown in Table 2, the average available nitrogen contents in the $0-20 \mathrm{~cm}$ soil layers were higher in Eucommia ulmoides plantation and Pinus massoniana forest i.e., 83.58 and $83.86 \mathrm{mg} \cdot \mathrm{kg}^{-1}$, respectively. The average nitrogen content in the slope farmland was the lowest $\left(66.91 \mathrm{mg} \cdot \mathrm{kg}^{-1}\right)$. In the $0-10-\mathrm{cm}$ soil layer, the difference between the available nitrogen contents in the soil of the maple-Cinnamomum 
camphora mixed plantation and Eucommia ulmoides plantation was significant ( $\mathrm{P}<0.05)$, but the difference between them in the $10-20-\mathrm{cm}$ soil layer was not significant $(\mathrm{P}<0.05)$. The content of available phosphorus in the soil of slope farmland was the highest $\left(2.79 \mathrm{mg} \cdot \mathrm{kg}^{-1}, \mathrm{P}<0.05\right), 4.5$ times that in the soil of the mapleCinnamomum camphora mixed plantation (the lowest, $0.61 \mathrm{mg} \cdot \mathrm{kg}^{-1}$ ). On the other hand, the average available potassium content in the soil of slope farmland was also the highest $\left(112.82 \mathrm{mg} \cdot \mathrm{kg}^{-1}\right)$, followed by that of the Eucommia ulmoides plantation $\left(90.37 \mathrm{mg} \cdot \mathrm{kg}^{-1}\right)$.

The available nutrients of all stands decreased with the increase of soil depth. Especially, the soil available nitrogen content of Pinus massoniana forest and Eucommia ulmoides plantation decreased from 108.36 and $96.60 \mathrm{mg} \cdot \mathrm{kg}^{-1}$ in the depth of $0-10 \mathrm{~cm}$ to 59.36 and $70.56 \mathrm{mg} \cdot \mathrm{kg}^{-1}$ in the depth of $10-20 \mathrm{~cm}$, respectively, indicating that the available phosphorus and potassium contents changed significantly with the soil depth among different forest stands.

\section{Soil microelements among different forest stands}

All the data on trace elements presented in Table 3 represents the average content from different forests stands within 0-10 and 10-20 cm soil depth profiles. The range of the trace elements followed a pattern like $\mathrm{Fe}>\mathrm{Mn}>\mathrm{Zn}>\mathrm{Pb}>\mathrm{Ni}>\mathrm{Cu}>\mathrm{Cd}$. On the other hand, $\mathrm{Fe}, \mathrm{Mn}, \mathrm{Zn}, \mathrm{Pb}, \mathrm{Ni}, \mathrm{Cu}$ and $\mathrm{Cd}$ content through $0-10 \mathrm{~cm}$ soil layers were ranked as Eucommia ulmoides plantation > slope farmland > Pinus massoniana forest > maple-Cinnamomum camphora mixed plantation.

Table 3. Showing the content of soil trace elements in different forest stand types

\begin{tabular}{|c|c|c|c|c|c|c|c|c|}
\hline Stand type & Soil layer $(\mathbf{c m})$ & $\begin{array}{c}\mathbf{C u} \\
\left(\mathrm{mg} \cdot \mathbf{k g}^{-1}\right)\end{array}$ & $\begin{array}{c}\mathbf{F e} \\
\left(\mathbf{m g} \cdot \mathbf{k g}^{-1}\right)\end{array}$ & $\begin{array}{c}\mathbf{Z n} \\
\left(\mathbf{m g} \cdot \mathbf{k g}^{-1}\right)\end{array}$ & $\begin{array}{c}\mathbf{M n} \\
\left(\mathbf{m g} \cdot \mathbf{k g}^{-1}\right)\end{array}$ & $\begin{array}{c}\mathbf{C d} \\
\left(\mathbf{m g} \cdot \mathbf{k g}^{-1}\right)\end{array}$ & $\begin{array}{c}\mathbf{N i} \\
\left(\mathbf{m g} \cdot \mathbf{k g}^{-1}\right)\end{array}$ & $\begin{array}{c}\mathbf{P b} \\
\left(\mathbf{m g} \cdot \mathbf{k g}^{-1}\right)\end{array}$ \\
\hline \multirow{2}{*}{ Pinus massoniana forest } & $0-10$ & 4.30 & 4582.05 & 32.13 & 83.24 & 0.53 & 9.24 & 32.58 \\
\hline & $10-20$ & 4.60 & 4483.64 & 28.31 & 60.97 & 0.14 & 8.01 & 29.97 \\
\hline \multirow{2}{*}{$\begin{array}{c}\text { Maple-Cinnamomum } \\
\text { camphora mixed plantation }\end{array}$} & $0-10$ & 7.84 & 4941.38 & 48.49 & 478.68 & 0.53 & 16.63 & 37.81 \\
\hline & $10-20$ & 7.55 & 637.97 & 53.48 & 551.08 & 0.53 & 16.63 & 37.81 \\
\hline \multirow{2}{*}{$\begin{array}{c}\text { Eucommia ulmoides } \\
\text { plantation }\end{array}$} & $0-10$ & 10.79 & 5001.27 & 54.40 & 718.17 & 0.27 & 25.87 & 29.97 \\
\hline & $10-20$ & 11.68 & 4997.00 & 53.71 & 729.31 & 0.40 & 24.64 & 29.97 \\
\hline \multirow{2}{*}{ Slope farmland } & $0-10$ & 8.73 & 4958.49 & 51.04 & 695.89 & 0.40 & 21.56 & 29.97 \\
\hline & $10-20$ & 9.61 & 4937.11 & 50.93 & 662.47 & 0.40 & 24.03 & 24.74 \\
\hline
\end{tabular}

In detail, Fe contents in $0-10$ and $10-20 \mathrm{~cm}$ soil layers showed a range of 637.98 $5001.27 \mathrm{mg} \cdot \mathrm{kg}^{-1}$. However, the average Fe content in the soil of Eucommia ulmoides plantation was the highest but the concentration of it in the soil of maple-Cinnamomum camphora mixed plantation was the lowest. On the other hand, $\mathrm{Cu}$ contents ranged from $4.30-11.68 \mathrm{mg} \cdot \mathrm{kg}^{-1}$. It was highest in the soil of Eucommia ulmoides plantation but lowest in the Pinus massoniana forest. The Zn content varied from $28.31-54.40 \mathrm{mg} \cdot \mathrm{kg}^{-}$ 1. In Eucommia ulmoides plantation, this parameter was the highest while in the Pinus massoniana forest it was lowest. Mn contents showed a range of $60.97-729.31 \mathrm{mg} \cdot \mathrm{kg}^{-1}$ representing the highest value in the soil of Eucommia ulmoides plantation. Its concentration fell to a lower value in the soil of Pinus massoniana secondary forest. The recorded range of Cd content was $0.15-0.53 \mathrm{mg} \cdot \mathrm{kg}^{-1}$. The soil of maple-Cinnamomum camphora mixed plantation showed the highest concentration of $\mathrm{Cd}$. Another trace element $\mathrm{Ni}$ ranged from $8.01-25.87 \mathrm{mg} \cdot \mathrm{kg}^{-1}$ showing its highest presence in the soil of 
Eucommia ulmoides plantation. In the soil of Pinus massoniana forest low $\mathrm{Ni}$ concentration was seen. $\mathrm{Pb}$ varied from $24.74-37.81 \mathrm{mg} \cdot \mathrm{kg}^{-1}$ showing its highest concentration in the soil of maple-Cinnamomum camphora mixed plantation. The average $\mathrm{Fe}$ content in the soil of Eucommia ulmoides plantation decreased from $5001.27 \mathrm{mg} \cdot \mathrm{kg}^{-1}$ in the depth of $0-10 \mathrm{~cm}$ to $4995.55 \mathrm{mg} \cdot \mathrm{kg}^{-1}$ in the depth of $10-20 \mathrm{~cm}$. While its concentration greatly decreased in the soil of maple-Cinnamomum camphora mixed plantation. The decreasing pattern was $4941.38 \mathrm{mg} \cdot \mathrm{kg}^{-1}$ in the depth of $0-10 \mathrm{~cm}$ to $637.97 \mathrm{mg} \cdot \mathrm{kg}^{-1}$ in the depth of $10-20 \mathrm{~cm}$. In addition, the contents of trace elements in the soil of Pinus massoniana forest and slope farmland also showed the similar trend with the increase of soil depth. To sum up, it could be mentioned here that the contents of trace elements in the soil of different forest stands decreased with the increase of soil depth. It indicates that the contents of trace elements in the upper soil layer were much higher than those in the lower soil layer.

\section{Correlation between soil nutrient contents}

The results of correlation analysis between different soil nutrients for different stands are shown in Table 4.

Table 4. Showing the values of correlation coefficient ( $r$ ) among different soil nutrient parameters

\begin{tabular}{|c|c|c|c|c|c|c|c|c|c|c|c|c|c|c|}
\hline Index & \begin{tabular}{|c|}
$\begin{array}{c}\text { Organic } \\
\text { matter }\end{array}$ \\
\end{tabular} & \begin{tabular}{|c|} 
Total \\
$\mathbf{N}$ \\
\end{tabular} & $\begin{array}{c}\text { Total } \\
\mathbf{P}\end{array}$ & \begin{tabular}{c|} 
Total \\
K
\end{tabular} & \begin{tabular}{c|}
$\begin{array}{c}\text { Available } \\
\text { nitrogen }\end{array}$ \\
\end{tabular} & $\begin{array}{c}\text { Available } \\
\text { phosphorus }\end{array}$ & $\begin{array}{l}\text { Available } \\
\text { potassium }\end{array}$ & $\mathbf{C u}$ & $\mathrm{Fe}$ & $\mathbf{Z n}$ & Mn & Cd & $\mathbf{N i}$ & $\mathbf{P b}$ \\
\hline \multicolumn{15}{|l|}{ Organic matter } \\
\hline Total N & 0.47 & & & & & & & & & & & & & \\
\hline Total P & -0.45 & 0.26 & & & & & & & & & & & & \\
\hline Total K & -0.42 & 0.49 & $0.94 *$ & & & & & & & & & & & \\
\hline $\begin{array}{c}\text { Available } \\
\text { nitrogen }\end{array}$ & 0.77 & 0.77 & -0.41 & -0.17 & & & & & & & & & & \\
\hline $\begin{array}{l}\text { Available } \\
\text { phosphorus }\end{array}$ & -0.64 & -0.60 & 0.59 & 0.32 & $-0.95^{*}$ & & & & & & & & & \\
\hline $\begin{array}{l}\text { Available } \\
\text { potassium }\end{array}$ & -0.72 & -0.12 & $0.92 *$ & 0.79 & -0.73 & 0.83 & & & & & & & & \\
\hline $\mathrm{Cu}$ & -0.38 & 0.42 & $0.98^{*}$ & $0.98^{*}$ & -0.25 & 0.44 & 0.85 & & & & & & & \\
\hline $\mathbf{F e}$ & 0.24 & -0.14 & 0.40 & 0.11 & -0.36 & 0.59 & 0.37 & 0.30 & & & & & & \\
\hline $\mathbf{Z n}$ & -0.64 & 0.32 & 0.88 & $0.96^{*}$ & -0.30 & 0.38 & 0.83 & $0.91 *$ & \begin{tabular}{|l|}
-0.07 \\
\end{tabular} & & & & & \\
\hline Mn & -0.62 & 0.23 & $0.96^{*}$ & $0.96^{*}$ & -0.43 & 0.55 & $0.92 *$ & $0.96 *$ & 0.16 & $0.97 *$ & & & & \\
\hline Cd & -0.64 & -0.07 & -0.08 & 0.15 & -0.05 & -0.18 & 0.05 & -0.02 & \begin{tabular}{|l|}
-0.90 \\
\end{tabular} & 0.38 & 0.19 & & & \\
\hline $\mathrm{Ni}$ & -0.49 & 0.26 & $1.00 * *$ & $0.95^{*}$ & -0.41 & 0.58 & $0.92 *$ & $0.99 *$ & 0.35 & $0.91 *$ & $0.98 *$ & -0.02 & & \\
\hline $\mathbf{P b}$ & 0.01 & 0.37 & -0.43 & -0.10 & 0.60 & -0.77 & -0.50 & -0.29 & $-0.96 *$ & 0.01 & -0.23 & 0.76 & -0.38 & 1 \\
\hline
\end{tabular}

The symbol * is added if $P$ was $<0.05$; the symbol $* *$ is added if $P$ was $<0.01$

Total phosphorus showed a positive correlation with total potassium $(r=0.94, \mathrm{P}<$ 0.05). This parameter also showed significant positive correlation with the contents of $\mathrm{Cu}, \mathrm{Mn}$ and $\mathrm{Ni}(r=0.98, \mathrm{P}<0.05) ; r=0.96, \mathrm{P}<0.05)$ and $\mathrm{r}=1, \mathrm{P}<0.01)$, respectively). In the analysis, total potassium correlated significantly and positively ( $\mathrm{P}<$ 0.05 ) with the contents of $\mathrm{Cu}, \mathrm{Zn}, \mathrm{Mn}$ and $\mathrm{Ni}$, (the values of $r$ were $0.98,0.96,0.96$ and 0.95, respectively). Among these trace elements, $\mathrm{Cu}$ had significantly positive relationships with the contents of $\mathrm{Mn}$ and $\mathrm{Ni}(\mathrm{P}<0.05)$, and the correlation coefficients were 0.96 and 0.99 , respectively. Zn correlated significantly and positively with $\mathrm{Mn}(r=$ 
0.97, $\mathrm{P}<0.05)$. Mn showed significant positive correlation with $\mathrm{Ni}(\mathrm{r}=0.98, \mathrm{P}<0.05)$. Significant negative correlation was observed between $\mathrm{Fe}$ and $\mathrm{Pb}(r=-0.96, \mathrm{P}<0.05)$.

\section{Discussion}

\section{Effects of returning farmland to forest on the different soil nutrient contents}

The interactions between soil and vegetation promote the change of spatial heterogeneity of soil and vegetation, and soil quality is the result of interactions between human and natural factors (Wang et al., 2010a). In the present work, the results showed that after returning farmland to forest, the organic matter contents in the soil of different forest stands were ranked as follows: Pinus massoniana forest $>$ slope farmland > Eucommia ulmoides plantation > maple-Cinnamomum camphora mixed plantation. The reasons can be summarized as follows: The root system of Pinus massoniana secondary forest was more developed, and the canopy width was greater with more litter. Because of long-term fertilization, the organic matter content of slope farmland was high. Hence, the carbon source input of Pinus massoniana forest and slope farmland was high. The Eucommia ulmoides plantation accumulated abundant organic matter under the conditions of manual disturbance and cultivation management. The maple-Cinnamomum camphora mixed plantation was a secondary forest, of which the accumulation of organic matter was less affected by external factors. Therefore, its organic matter content was lower. The soil organic matter, as a cementing material between soil particles, can form water-resistant aggregates and large aggregates with moderate ratios and stable structures (Albiach et al., 2001). Hence, it has the ability to enhance soil and water conservation and to improve soil structure, thereby enhancing the ability of decomposing litter and leaves and improving the nutrients exchange rate between plants and soil. As a result, a benign circulation system will be formed.

The contents of total nitrogen, total phosphorus and total potassium in the soil of different forest stands after returning farmland to forest were relatively high, indicating that the soil in this area was not barren. Compared with the slope farmland, the total nitrogen content in the soil of Eucommia ulmoides plantation was the highest, principally because the soil nitrogen content mainly depended on the decomposition extent of organic matter and the accumulation of biomass. The Eucommia ulmoides plantation had high species diversity, and the biomass accumulation of shrubs and herbs was high also. Thereby, the return, decomposition and enrichment of nutrients were intense. Qi et al. (2007) also reported that the soil nitrogen content mainly depended on the decomposition extent of organic matter and accumulation of biomass. Except the slope farmland, the Pinus massoniana forest, Eucommia ulmoides plantation and the maple-Cinnamomum camphora mixed plantation were rich in understory vegetation, litter and biomass, which favored the accumulation of organic matter and nitrogen. The higher contents of organic matter also benefited the contents of nitrogen and phosphorus. The high contents of total potassium should be ascribed to the soil parent material in this area. The potassium in the soil mainly existed in the form of minerals. Thus, the supply level of potassium in the soil mainly depended on the amount of potassium minerals in the soil, so the potassium content in this area was enough. The results of our study showed that the soil organic matter in the woodlands, after returning farmland to forest, had been improved, indicating that the returning was beneficial to the accumulation of soil organic matter. This result is consistent with the results of Han et al. (2012) and Gong et al. (2005). Gong et al. (2005) also reported that the differences 
between soil organic matter contents in different soil layers of various forest stands were significant.

It is assumed that the content of available nutrients serves as an indicator for the supply of soil nutrients (Wang et al., 2014). The results in this work showed that the average content of soil available nitrogen in 0-10 and 10-20 cm layers was higher than $78 \mathrm{~g} \cdot \mathrm{kg}^{-1}$. The average content of available phosphorus was lower than $1.35 \mathrm{~g} \cdot \mathrm{kg}^{-1}$ and the average content of available potassium was lower than $75 \mathrm{~g} \cdot \mathrm{kg}^{-1}$. The variation trend of the available nitrogen content in this region was in agreement with that of the total nitrogen content. According to the dynamic variation laws of nutrients in forest soil, the content of organic matter should be positively correlated with the content of soil available nitrogen to a certain extent (Yang and Zhang, 1986). Namely, the higher the organic matter content, the higher the available nitrogen content is. In the $0-10 \mathrm{~cm}$ soil layer, the contents of available nitrogen, available phosphorus and available potassium in the soil of Eucommia ulmoides plantation were relatively high. Because the litter fall from a relatively wide canopy of Eucommia ulmoides plantation was intense. This results a high content of organic carbon in the upper soil layer (Wang et al., 2010b), which was favorable to the accumulation of nitrogen and phosphorus.

After returning from farmland to forest, the contents of soil organic matter, total phosphorus and nitrogen and available potassium, phosphorus and nitrogen decreased with the increase of soil depth among various forest stands. This is because the soil nutrients generated mainly from soil minerals and soil organic matter and the latter compound is mainly generated from the litter of aboveground parts, underground roots, precipitation, slope infiltration, groundwater, fertilization and irrigation during cultivation. Therefore, most of the sources of soil nutrients were above ground, and these sources first contacted with the upper soil layer for enriched storage. Then, the nutrients were transported to the lower layer through leaching or uptake with roots. Consequently, the contents of organic matter, total phosphorus and nitrogen and available potassium phosphorus and nitrogen in the soil of different forest stands declined with the increase of soil depth.

\section{Relationship between soil nutrients after returning farmland to forest}

The contents of trace elements in the soil of different forest stands followed the order: $\mathrm{Fe}>\mathrm{Mn}>\mathrm{Zn}>\mathrm{Pb}>\mathrm{Ni}>\mathrm{Cu}>\mathrm{Cd}$. The soluble Fe species could be involved in the growth of plants (Qi et al., 2008), so the content of Fe was high. All the organics and biological residues in the soil contained $\mathrm{Zn}$ and the acidic substances produced from organic matter during decomposition could increase the solubility of $\mathrm{Zn}$ compounds. The order of total contents of soil trace elements in the soil of different stands was ranked as follows: Eucommia ulmoides plantation > slope farmland > Pinus massoniana forest > maple-Cinnamomum camphora mixed plantation. In addition, generally the total contents of trace elements in the $0-10 \mathrm{~cm}$ soil layers were higher than those in the $10-20 \mathrm{~cm}$ soil layers. This is mainly due to the compensation effect of litter decomposition, nutrients release and return on the contents of trace elements in soil. This distribution phenomenon also reflects the weak leaching and deposition effects in the lower soil layers.

Based on the correlation analyses among soil nutrients of different forest stands after returning farmland to forest, the positive correlations between the content of soil organic matter and the contents of total and available nitrogen were found. This indicated that nitrogen and carbon elements were closely related in the accumulation 
and storage process. This result is in accordance with the conclusion of $\mathrm{Li}$ et al. (2014) that the content of organic matter in soil had significantly positive correlations with the contents of total nitrogen, available nitrogen, total phosphorus and available phosphorus in the soil. On the other hand, Li et al. (2014) also found that the content of organic matter in soil correlated positively but weakly with the contents of soil total potassium and available potassium. This result was also consistent with the present study. Additionally, in the present work, we found that the content of phosphorus in soil was significantly positively correlated with the contents of trace elements $\mathrm{Cu}, \mathrm{Mn}$ and $\mathrm{Ni}$. This result agrees with the conclusions drawn by Huang et al. (2016), who reported that the contents of $\mathrm{Cu}, \mathrm{B}$, and $\mathrm{N}$ were significantly positively correlated with various minerals in the soil for the cultivation of wild tara vine. In this study, the content of total potassium was significantly positively correlated with contents of $\mathrm{Cu}, \mathrm{Zn}, \mathrm{Mn}$ and $\mathrm{Ni}$, but Huang et al. (2016) suggested that the content of total potassium was significantly and negatively correlated with contents of $\mathrm{Cu}, \mathrm{Zn}, \mathrm{Ni}$ and other elements. This difference should be attributed to the reason that the soil used in Huang's study was acidic black loam located at the foot of the Changbai Mountain in Antu County, Yanbian Prefecture, Jilin Province, China, and the black loam, containing a small amount of soluble salts, had a great texture without salinization. As for the soil in our present work, the red and yellow soil had a parent material of shale and slate, and the soil texture was poor, compared to the black loam. These results show that the distribution of soil nutrients depends on the structural factors such as climate, topography, parent material and soil type which can lead to the spatial relationships between soil nutrients.

In this study, the content of $\mathrm{Cu}$ was correlated significantly and positively with $\mathrm{Mn}$ and $\mathrm{Ni}$. On the other hand, Zn correlated significantly and positively with $\mathrm{Mn}$. Mn however, correlated significantly and positively with $\mathrm{Ni}$. In this study significant negative correlation was observed between $\mathrm{Fe}$ and $\mathrm{Pb}$. These results indicate that the trace elements in various types of soil interacted with each other showing a pattern that, when the content of an element increased, the contents of relative trace elements changed.

\section{Conclusion}

After returning farmland to forest (i.e., Grain to Green), the accumulation of soil organic matter in the soil of the three vegetation types and slope farmland was increased, but the accumulation was different depending upon the vegetation types. The accumulation in the soil of Pinus massoniana forest was the highest, and that of the maple-Cinnamomum camphora mixed plantation was the lowest. In the vertical direction, the contents of organic matter in the soil of all forest stands were decreased. After returning farmland to forest, the contents of total nitrogen, phosphorusand potassium and organic matter in the soil of woodlands were the highest and those in the soil of the slope farmland were the lowest. This had indicated that the accumulation of nutrients in the soil of slope farmland was slower. Nevertheless, the accumulation of available nutrients in the soil of slope farmland was the fastest. The contents of available nitrogen and available phosphorus decreased with the increase of soil depth, but the content of available potassium increased with the increase of soil depth. After returning farmland to forest, the trace elements accumulated to a small extent but their differences based on different stands were negligible. The nutrient elements in the soil 
of different vegetation types had significant correlations with each other and the soil trace elements interacted with each other following a pattern that when the content of an element increased, the contents of relative trace elements changed.

In addition, only the correlation between soil nutrients were studied in this research, and many other future studies such as dynamic changes of nutrient, change mechanism and so on would also play an important role in nutrient cycling research. And this needs to be studied further in the future. The result of this research can provide data support and theoretical basis for soil conservation, vegetation optimization model selection and artificial control in the erosion area of southern mountainous range of China.

Acknowledgements. The present research work was supported by the grant of Forestry Science and Technology Plan Project in Hunan (XLC201701-2), Major Research and Development Program in Hunan (2017NK2223), Forestry Science and Technology Plan Project in Hunan (XLKPT201703, XLKPT201706, XLKPT201707, XLKPT201710), National Science and Technology Plan for Twelfth Five-Year in the Countryside (2015BAD07B04), National Key R \& D Program of China (2017YFC0505506), Forestry Science and Technology Project in Hunan (2012-HNLYKY-01) and CFERN \& BEIJING TECHNO SOLUTIONS Award Funds on excellent academic achievements. All these supports are duely acknowledged with thanks.

\section{REFERENCES}

[1] Albiach, R., Canet, R., Pomares, F. (2001): Organic matter components and aggregate stability after the application of different amendments to a horticulture soil. - Bioresource Technology 76(2): 125-129.

[2] Augusto, L., Ranger, J., Binkley, D., Rothe, A. (2002): Impact of several common tree species of European temperate forests on soil fertility. - Annals of Forest Science 59(3): 233-253.

[3] Cao, Y. S., Wu, F. Y., Xiao, Y. A. (2016): Effect of returning farmland to forests on soil nutrients contents and its vertical distribution. - Ecology and Environmental Sciences 25(2): 196-201.

[4] Chen, S., Yuan, Z. L., Yao, S. (2017): Soil nutrients research on Pinus tabulaeformisQuercus aliena var. acuteserrata mixed forest in Baotianman national nature reserve. Henan Science 35(12): 1945-1951.

[5] Finzi, A. C., Van Breemen, N., Canham, C. D. (1998): Canopy tree-soil interactions within temperate forests: species effects on soil carbon and nitrogen. - Ecological Applications 8(2): 440-446.

[6] Gong, J., Chen, L. D., Fu, B. J., Hu, C. X., Wei, W. (2005): Effects of vegetation restoration on soil nutrient in a small catchment in Hilly Loess area. - Journal of Soil and Water Conservation 19(1): 93-96.

[7] Han, X. H., Tong, X. G, Yang, G. H. (2012): Difference analysis of soil organic carbon pool in returning farmland to forest in loess hilly area. - Transactions of the Chinese Society of Agricultural Engineering 28(12): 223-229.

[8] He, H. J., Wang, H. Q., Tao, Y. H. (2017): Study on soil nutrient of three types of plantations at Shatang forestry farm in Guangxi. - Journal of Guangxi Science \& Technology Normal University 32(5): 127-130.

[9] Hu, F., Du, H., Zeng, F. P. (2018): Dynamics of soil nutrient content and microbial diversity following vegetation in a typical karst peak-cluster depression landscape. - Acta Ecologica Sinca 38(6): 1-9.

[10] Huang, C. Y. (2000): Agrology. - Beijing: China Agriculture Press.

[11] Huang, Y. B., Cao, W. W., Xu, L. (2016): Wild actinidia arguta habitat soil nutrient content and correlation analysis. - Journal of Anhui Agriculture Science 44(18): 14-115. 
[12] Huang, K. C., Shen, Y. Y., Xu, G. P., Huang, Y. Q., Zhang, D. N., Sun, Y. J., Li, Y. Q., He, W., Zhou, L. W. (2018): Effects of reclamation on soil nutrients and microbial activities in huixian Karst Wetland in Guilin. - Environmental Science 22(4): 1813-1823.

[13] Jiang, H. M., Li, M. Z, Wang, Q. (2011): Dynamics of soil nutrients under different vegetation types in the eastern Qilian Mountains. - Research Soil and Water Conservation 18(5): 166-170.

[14] Latty, E. F., Canham, C. D., Marks, P. L. (2004): The effects of land-use history on soil properties and nutrient dynamics in northern hardwood forest of the Adirondack mountains. - Ecosystems 7(2): 193-207.

[15] Li, Y., Man, X. L., Cai, T. J. (2014): Research on soil nutrient characteristic and correlation in different slope position of scotch pine forest in Da Hinggan Mountains. Journal of Anhui Agriculture Science 42(5): 1413-1416,1420.

[16] Liu, Q. Y., Tong, Y. P. (2005): Effects of land use type on soil nutrient distribution in northern agro-pasture ecotone. - Chinese Journal of Applied Ecology 16(10): 1849-1852.

[17] Liu, Z. K., Wang, S. P., Chen, Z. Z., Wang, Y. F., Han, J. G. (2006): Properties of soil nutrients and plant community after rest grazing in Inner Mongolia steppe. - Acta Ecologica Sinca 26(6): 2048-2056.

[18] Lopes, V. L., Canfield, H. E. (2004): Effects of watershed representation on runoff and sediment yield modeling. - Journal of the American Water Resources Association 40(2): 311-319.

[19] McGrath, D. A., Smith, C. K., Gholz, H. L., Oliviera, F. (2001): Effects of land-use change on soil nutrient dynamics in Amazonian. - Ecosystems 4(7): 625-645.

[20] Peng, X. D., Dai, Q. H., Li, C. L. (2018): Output mechanism of soil nutrients from karst slope farmland under simulated rainfall. - Acta Ecologica Sinca 38(2): 1-9.

[21] Qi, L. H. (2007): Ecological characteristics of vegetation restoration for degraded lands in a watershed, Wulin mountain region. - Beijing: China Academy of Forestry Sciences.

[22] Qi, L. H., Zhang, X. D., Peng, Z. H. (2008): Soil microelements under different vegetation restoration patterns in yellow soil slope region of mid-subtropics. - Chinese Journal of Applied Ecology 19(4): 735-740.

[23] Wang, G. L., Liu, Z. B., Xu, M. X. (2001): Effect of vegetation restoration on soil nutrient changes in Zhifanggou watershed of loess hilly region. - Bulletin of Soil and Water Conservation 22(1): 1-5.

[24] Wang, J., Fu, B. J., Qiu, Y., Chen, L., Yu, L. (2002): Spatial heterogeneity of soil nutrients in a small catchment of the Loess Plateau. - Acta Ecologica Sinca 22(8): 11731178 .

[25] Wang, Z. M., Zhang, B., Song, K. S., Liu, D. W., Li, J. P., Huang, J., Zhang, H. L. (2007): Analysis of related factors for soil nutrients in croplands of typical agricultural county, Northeast Plain, China. - Journal of Soil and Water Conservation 21(2): 73-77.

[26] Wang, J., Lv, Z. Z., Qian, Y. (2010a): Soil nutrients under vegetation cover of different desert landscapes in junggar Basin, Xinjiang. - Journal of Desert Research 30(6): 13761373.

[27] Wang, J. L., Wang, Z. H., Zhang, X. Z. (2010b): Effect on alpine vegetation of different grassland ecosystems composed of soil organic carbon and water stable aggregates content. - Acta Agrestia Sinica 18(6): 749-757.

[28] Wang, Q. Y., Zhang, F. H. (2014): Soil nutrient properties under typical halophytic vegetation community in arid region. - Journal of Soil and Water Conservation 28(5): 235-241.

[29] Ward, D., Trinogga, J., Wiegand, K., du Toit, J., Okubamichael, D., Reinsch, S., Schleicher, J. (2018): Large shrubs increase soil nutrients in a semi-arid savanna. Geoderma 310: 153-162.

[30] Wei, X. R., Shao, M. A. (2007): The distribution of soil nutrients on sloping land in the gully region watershed of the Loess Plateau. - Acta Ecologica Sinca 27(2): 603-612. 
[31] Wen, Z. M., Jiao, F., Liu, Z. Y. (2005): Natural vegetation restoration and soil nutrient dynamics of abandoned farmlands in forest-steppe zone on Loess Plateau. - Chinese Journal of Applied Ecology 16(11): 2025-2029.

[32] Xiang, Z. Y., Zhang, L., Zhang, Q. F. (2014): Soil nutrients and microbial functional diversity of different stand types in Qinghai Province. - Scientia Silvae Sinicae 50(4): 2231.

[33] Yan, E. R., Wang, X. H., Chen, X. Y. (2007): Impacts of evergreen broad-leaved forest, degradation on soil nutrients and carbon pools in Tiantong, Zhejiang Province. - Acta Ecologica Sinca 27(4): 1646-1655.

[34] Yang, C. D., Zhang, W. R. (1986): Research on forest soil organic matter in Wolong nature reserve. - Acta Pedologica Sinica 23(1): 30-38.

[35] Yuan, Z. J., Cai, Q. G., Qing, J. (2006): Runoff and sediment characteristics of different land use in Hemingguan watershed. - Resources Science 28(1): 70-74.

[36] Zhang, H. X., Zeng, Q. C., An, S. S. (2018): Soil enzyme activities soil and leaf litter nutrients of typical vegetation in Ziwuling Mountain. - Acta Ecologica Sinca 38(7): 1-9. 